\title{
Understanding of Current Higher Education System: A focus on the Interpretation of Marxism Over Time
}

\begin{tabular}{ll} 
ARTICLE INFO & Youngsik Hwang \\
\hline $\begin{array}{l}\text { Article History: } \\
\text { Received 16.10.2020 }\end{array}$ & $\begin{array}{l}\text { This paper discusses the role of Marxism to understand the current higher education system in terms } \\
\text { of the theoretical lens. Marxism has been the academic foundation to explain various regimes of } \\
\text { Received in revised } \\
\text { communism in some areas of the world, and it still has an impact on the theoretical background to } \\
\text { foscribe specific characteristics of industrial development over time. While prior studies have } \\
\text { Accepted }\end{array}$ \\
$\begin{array}{l}\text { Available online } \\
\text { e1.1†.2021 }\end{array}$ & $\begin{array}{l}\text { are rare studies that combine the current development of the current higher education system. This } \\
\text { study provides the importance of Marxism to the higher education system and how the theoretical } \\
\text { approach justifies diverse characteristics of current higher education development. Finally, this } \\
\text { research shows the aspects of the revised Marxism framework that could explain the current higher } \\
\text { education system and give implications for higher education researchers to reorganize the current } \\
\text { educational system. }\end{array}$
\end{tabular}

C IJERE. All rights reserved

Keywords: Marxism, higher education system, educational purpose, revised Marxism framework

\section{INTRODUCTION}

Marxism has been played huge roles to support the political regimes in various regions and affects the following scholars who are interested in the property of communism, class and relevant classical terminologies in the world. The social, economic, and ideological perspectives of the theoretical lens have more politically direct dialogues, such as revolution, capitalist exploitation, and the vanguard of the working class (Anyon, 1994). After several experimental trials and practical execution on the world stage, those terms seemed to have lost a sense of possibility to explain different phenomena in reality, and the initial ideas that come into Marxist's perspectives have been required to adapt to the truth differently. Globalization and internationalization in higher education work their way into the practice of university administration in the world and seeing new theoretical foundations around the higher education system becomes more important to satisfy the diverse needs outside (Cantwell \& Maldonado-Maldonado, 2009). This has come up with the necessity of a transformative theoretical and empirical foundation about how society makes better political and economic development. While Marxism traditionally refers to economic determinism where the financial foundation critically affects other levels of organization (Cole, 2005), following neo-liberal capitalism is deepening its vast effects on all aspects of everyday life (Hill, 2005; Hill, Rowan, \& Ball., 2005). In the process, Marxism is required to transform to meet the flexible environment. The systemic inefficiency of former Soviet Union nations harms faculty productivity, and the given inadequacy of the public sector education provides alternative ways to serve prospective students for a better return. Based on the value of fairness and impartiality, current students with different moral principles stand up for the credible education system (Heyneman, 2010). Hill (2003) notes that while the determining motivation of the market is to meet the need of consumers through purchasing goods. This only satisfies the motivation of some cohorts that can buy the products. The place of education, he acknowledges the expansion of knowledge transfers in terms of the development of cognitive capacity, and the satisfaction with consumers depends on their free will. The old concept of Marxism has a chance to be reconsidered as its theoretical justification for the higher education system at this moment.

This study provides a different approach to Marxism to overview the current higher education system. Although the Marxism effect of theoretical adoption to the society in the world is declined from the devastation of communist societies in certain regions, there is no doubt that the approach creates unique terms and justification in the education field. The revised Marxism approach to explaining current higher education provides how the post-secondary institution builds a strategy to support potential education service consumers such as students and parents. The diverse interpretation of campus members and the aggressive action plan to lead possible changes outside from the theoretical lens implies how the institution builds a strategy to survive in the competitive market condition. Based on the proposed conceptual framework, this

${ }^{1}$ Chungnam National University, sleain158@gmail.com, orcid.org/0000-0003-4065-225X 
paper reviews the prior discussions about how a Marxism-driven educational approach affects the higher education system and the rationale behind the relationship between them.

\section{CONCEPTUAL FRAMEWORK}

\section{Marxism and the Purpose of Higher Education}

The higher education system has expanded its roles in society over time, and different theoretical frameworks have explained the flexible needs of the community to the higher education system. Marxism also has generated the new value of different terminology, mission, and relevant logical paradigm to explain the complexity of the higher education system. Balibar (1978) initially describes Marxism through theoretical irrationalism in the economic field. For intensive industrialization, theoretical rationalism focuses on the diverse style of limited growth, risk, and harmful effects. Higher education, in general, supports material improvement and rational strategic planning in the moment. On the other hand, the Marxism-centered perspective on the education system considers the role of the educational service in a different way. At the social level, the theoretical lens criticizes the crisis of capitalism and involves the revolution of existing contradictions against institutions and power relations. These stand for the refusal of typical rationalism and break dominant generalization for collective social relations and ideology. The revolutionary break with rationalism makes the higher education system change its educational purpose and mission. The Marxism against the typical dominant mass of campus, such as middle-class, white, repay attention to the importance of content and information to outcomes and results (Malott, 2006). Under the foundation of specific campus culture, the institution does its educational affairs to influence its members on campus. A political economy of educational innovation from Marxism elaborates on the importance of power between people and emphasizes the generation of correspondence and contradiction (Papagiannis, Klees, \& Bickel, 1982). In the process, the theoretical lens imbues its perspectives on the internal learning environment and interaction with others on campus. This approach acknowledges that the institutional knowledge transfer from student to instruction is a complex social phenomenon involving different layers of relevant internal and external forces (Perry \& Tor, 2008). This is a conceptual framework that the necessary foundation of the revised Marxism which means the educational consumer gets paid for the value they create, rather than get paid for how hard they work or how much time they put into it under the learning process. The organized dynamics do not reproduce more the unfair and unjust institution under the shaping of the biased ideology. The recent Marxism educators start to cast doubt on how the white majority dominates the contexts of curriculum, and the general notion of schooling is contingently constructed and reconstructed by the power relationship between campus members (Qi, 1997).

\section{Institutional Functioning of Marxism and Educational Value}

Marxism shows the different educational values, students' needs, and educational investment in terms of economic perspective. The extensive adjustment based on the theoretical lens executed their role under institutional setting, and diverse institutional function reflects the aspects of the relevant notions at some point. Brown (1995) explains the property of educational value through cultural capital and social exclusion. The demand for cultural capital is related to the reproduction and class location, and the need for marketing power in the competition co-exists with technological innovation, corporate restructuring, and the fluctuation of global market conditions. The institution has met the requirements of the flexible market condition for better effectiveness. In the process, the middle-class experiences drastic growth in economic development, and they want to get a value of equality to reveal their ability in the competition, and the educational institution which has a responsibility to train the class changes their mission to extend more mass. The growing interest for sustainable development among the emerging groups results in an inter-related economic and ecological crisis, and Marxist environmentalism investigates the possible solution to overcome the latent conflicts (Johnston, 1989; Soper, 1999; Dordoy \& Mellor, 2000). They acknowledge that the sustainable development of higher education requires to have the erosion of instrumental reason and the balance between organized social structure and people's collective interest (Huckle, 2004). A comprehensive adoption of these possible interpretations enables to have the ideas that relevant stakeholders could combine the institutional roles with intended educational values under a specific learning environment. This is one of the alternative ways to overcome a liminal, dialogical space between environmentalism, materialism, and other comparative 
education and offers a critical pedagogy in how the revised educational frontier could be interpreted in the institution (Ibrahim, 2007).

\section{College Student as a Class and New Paradigm}

The views about college students have changed over time, and different theories explain how students get their outcomes and expected returns through economic perspectives. Marxism also shows the new paradigm to explain the position of the student as a class and describes how students perceive their role and expect potential outcomes. Hill and Kumar (2012) acknowledge that a student is transformed into valuecreating labor in capitalism and considered as a labor force in terms of the existence of capital. In the production function, labor power contributes to making the whole production cycle for a commodity. Business wants to make a profit from different social areas, including education and the marketized perspectives accelerate to privatize of schools and educational services. Students learn more effectively for targeted goals such as better test scores and the transformed labor from a student are sold by the standard of monetary value. The representation of student accomplishment and potential as neutral is constructed in the intensification of discipline and punishment at some point. The terrifying and irrational efficiency of standardized tests in terms of power and functionary perspective reveals the weakness of capitalism and promote Marxism-centered educational accountability that appeals to its operation across the administrative and bureaucratic structure of institution (Lissovoy \& McLaren, 2003). Higher education and research have been playing significant roles to support the current knowledge-based economy, and college students are required to accumulate intellectual capital as well as having a connection with outside needs. This is transformed its symbolic images as economiccentered creativity-based education, and relevant educational activity includes analytic skills, affective skills, and tradeable knowledge (Michael, 2019). College students on campus set their position with the required skills and expertise in the learning process. The accumulated academic background based on the 'combined' experience is recognized as the educational value and validity fundamentally to evolve the community of inquiry (Peters \& Besley, 2006).

\section{LITERATURE REVIEW}

\section{Traditional Marxism for Education}

Previous studies based on Marxism have investigated the standard value of education in terms of hierarchy notions such as class. They focus more on why students choose a specific school and how the potential consumers for educational service relate to educational purposes over time. Initial Marxism represents the social practices as transitory, and all knowledge and intellectual formation reflect social relations and power (Olssen, 2004). This affected the structure of a social system, including different organizations in the society, and the conceptual framework acknowledges the importance of physical necessities for continuous historical relativity. Historical materialism is the concept of the social relation and internal structure of power relations (Olssen, 2004). Kellner (2006) explains the Marxian perspectives on educational philosophy. According to his description, the initial Marxist concepts of class and domination on capitalism is critical and has believed that the economic imperatives shape institutions like schooling to correspond to the interests of the ruling class. As more people get interested in entering the higher education system, a lot of structured programs or curricula force them to train more to fit the manipulated reconstruction of education. Torres (1995) recognizes the political aspects of education to solve the educational problem. He analyzes the relationship between education and state government and acknowledges that the dynamics of the relation have a multitude of tensions under historical fluctuation. The social forces affect the change of educational institutions, and political power is in the process. The traditional Marx's analysis of capitalism points out the dialectical contradiction that the internal relationship between labor and capital comes from the idea about how the value of wealth is produced and distributed (Allman, McLaren, \& Rikowski, 2005). Productive abilities of people from educational service facilitate the possible market trade in the community, and a unit of trained labor as a commodity is considered for exchange. Traditional Marxism acknowledges the importance of the relationship between schooling and potential production for economic development in their formulations $(\mathrm{Au}, 2006)$. He also shows the relationship between the industrial base and social structure is nonlinear, non-mechanistic, and non-deterministic. Through the analysis of previous debates among scholars, its finding provides a possibility against positing a one-tone correspondence between schooling and the economy. 


\section{Property of Marxism and Practical Adoption}

Marxism has its feature to explain existing reality, such as inequality, personal preference, and economic conditions. Some studies examine the internal notion of Marxism and try to have a practical explanatory for society. Alon (2009) confirms the importance of social class to affect the decision to college enrollment. The result shows that the class divide regarding enrollment and college access and especially, the tendency is remarkable for the admission of selective institutions. This accelerates the inequality of class through the reproduction of difference in higher education, and the negative circulation consolidates existing gaps of class in society. Marxism initially had started to grasp the inequitable reality and caused various social revolutions and reforms as an essential foundation of a theoretical framework. The theoretical lens includes the practical applications of the internal principle, and the social accountability in improving practices generates the different educational influences to communicate the meanings of the image of embodied values and lifeaffirming energy (Whitehead, 2009). Marx's views on education are to assess its practical value for capital, and the Marxist education theorists believe that the graduates are productive labor after the organized educational program, and it serves to replicate the dominant-subordinate nature of class relations from the labor-capital relationship on the capitalism (Greaves, Hill, \& Maisuria, 2007).

\section{Recent Overview of College and University through Marxism}

The current colleges and universities have changed their mission and internal structure to meet social demands. Marxism investigates the role of higher education institutions as well as forecasts how the different characteristics of postsecondary institutions interact with potential educational consumers. Marxists believe that individual desire can be educated, and political economy discounts the hold of capitalism (Brosio, 2004). The current higher education system reflects individual desire to improve, and the western style of capitalism governs the stream of institutional structure about how the organization emphasizes more for better performance.

Béchard and Grégoire (2005) acknowledge that a dominant preoccupation about the development of technology, cognitive process, collaborative learning, or business ethics is investigated by scholarly efforts of the university level, and the economic or business contents on campus are more accessible to improve students' entrepreneurship. Several relevant pedagogical dimensions, including the perspectives of Marxist educator, is under-addressed by current mainstream of educational research based on management learning and requires integrating with the diverse entrepreneurship courses into the research-grounded framework. The restructuring of education more fits for capital and transfer to the figure of egalitarian culture in the curriculum (Hill, 2007). A holistic and social class-based approach based on social and economic justice is in the education course and diversifies the targeted student groups in terms of multidimensional aspects. Steele and Taylor (2004) still acknowledge the valuable meaning of Marxism education, although there are several theoretical weaknesses and weaken explanatory power for the flexible externality. They believe the theoretical framework could analyze to engage in a dialogue with emerging social movements. Under the organized frame, the current postsecondary institution provides an opportunity for better behavioral engagement or reconstruction through alternative academic curricular for students, and the structured differentiation of advanced knowledge becomes the central concept for a more appropriate conceptualization of its role in the higher education system (Trowler, 2001; Young, 2012).

\section{GROWTH OF HIGHER EDUCATION AND MARXISM}

\section{Traditional Approach to explain Education System from Marxism}

Based on the Marxism educator's discussion above, the traditional framework to describe the role of higher education is consists of three aspects: 1) critiques for the current situation, 2) emphasis on the training system and 3) limitation of theoretical approach as a supportive tool. First, the traditional views based on Marxism are limited to accept the possibility of extensive adoption for endogenous growth of a system such as economic development. This applies to the higher education system since they have realized the necessity of its structural reform to meet emerging different needs outside. The introduction of Marxism has been correlated with explaining the contemporary contradiction of social inequality between people. More aggressive expression and a pessimistic forecast to capitalism instigated people to reconsider alternatives to solve the rampant social conflicts and required to generate new social values. This tendency reflects the 
orientation of the theoretical framework in the contemporary circumstance in which the contradiction of dominant capitalism shows up in the world. This was a kind of reaction against overcome the real difficulty from the weakness of capitalism and could be a blueprint for the lower social class in society. Secondly, Marxism initially tried to explain the purpose of education in terms of economic lens, and the expected return and outcomes were one of the main interests among the scholars in the field. Marxist educators have considered education for adults as one of the most critical areas, and the importance of educating for workingclass and disadvantaged groups in society is particularly emphasized (Steele \& Taylor, 2004). The role of higher education based on traditional Marxism is to produce future work to meet urgent social needs, and especially, they believed the curricular and academic program on campus is intended to have an idea that institutional functioning is correlated with the social needs. The last observation for higher education is that the traditional Marxism educator's perspectives depend on the possible student outcome for better performance. In order words, while these are not likely to be judged by what has to plan and its thoughts in the learning process, they are measured by what they do and the results they create. The object-oriented aspect relates to the empirical evidence of economic background, and the combination makes the education system be an ancillary role for a better society.

\section{Growth of Higher Education System and Theoretical Backgrounds}

The educational purpose is not only for any single targeting and but also has more diverse purposes with the development of society. Marxist educators initially considered the role of education in terms of training of working-class groups and emphasized narrowing down the gap of inequality from the different social classes. But the change of background of potential education consumers and different external needs make them consider different perspectives, far from the initial recognition of Marxism-centered educational goals. To avoid the limitation of explanatory power for reality, Marxist educators have tried to revise the initial version of the theoretical framework. The revised version generates a reasonable approach to why the students do their studies and how it relates to social development at the same time. First, the revision explains the rationale behind college student activity on campus in terms of academic curricular and extracurricular activity. The approach includes a comprehensive understanding of students' needs based on their different educational purposes, and it directly impacts important academic decisions such as significant choice, future career paths. Internal motivation to study on campus is not only oriented from the external rewards or economic returns anymore and become a part of the educational purpose. The emerging cognitive needs for different motivations play a role in explaining why college students pursuing a specific study on campus. Secondly, the revision contributes to generating a guideline of how an institution manages the different student needs on campus for becoming a suitable worker. The 'suitable worker' is not only the effective labor force to meet urgent social needs and also reflects an entire process of individual cognitive growth for a better life in the long run. While the rapidly growing industrial development was required to have well-trained employees to produce the obvious needs as a commodity, the recent knowledge-based social development, such as the fourth industrial revolution wants to blend diverse characteristics of ingredients including human capital, resources, and other materials. The revised theoretical approach is cooperative with the flexible process of social development and provides a more comprehensive understanding of the learning process of current students on campus.

\section{Reflection of Marxism for Current Higher Education System}

Marxism is necessary to be not isolated in a certain fixed lens to persuade its theoretical counterparts. The flexible social needs and growing diversity on campus require changing the initial interpretation and adoption of the contemporary higher education system. Marxism could not be imbued into the current educational issues with old terminology and customs and need the new value of education differently. The Marxist educator is no longer stuck in the language of 'class' from old-custom and accepts more diversity from different backgrounds of people such as minority, female, and low socioeconomic status students. The extensive adoption makes them enable to generalize interpretation for reality more and afford to access a flexible learning environment. There is more open access to the advanced educational service over time, and the institution does not control all kinds of different students any longer. This diversity makes Marxism have difficulty in categorizing the purpose of student behavior on campus as a single concept. The more diverse student enrollment on campus, the more complicated institutional strategies are required for better institutional performance. The revised theoretical lens from Marxism buffers the possible limitation of 
institutional functioning to support a diverse student body and cover the internal purpose of student action. This is an independent perspective far from the initial scope of the theoretical lens, which is deeply engaged in economic view.

\section{METHODOLOGY}

This study used to overview the previous literature and theoretical approaches on Marxism. The interpretation of prior studies provide diverse lens howscholars have discussed the role of Marxism in the higher education system. The theoretical approaches on Marxism highlights the interpretation of the theoretical lens in different ways and inform the new adoption of specific Marxism terminology in flexible higher education system over time.

\section{LOGICAL CORRESPONDENCE BETWEEN HIGHER EDUCATION AND MARXISM}

\section{Dominant Norms and Gearing of Higher Education System: Marxism-Oriented}

While the 'class' was classified as the public by specific steps of their background: lower and upper level. For the initial Marxism era, the meaning of the terminology is recently more diverse and reflects the multidimensional aspect of the higher education system. Class is no longer a particularly distinct group of people by their background as a representative terminology, and it just classifies the literal meaning of class division with more diversity. The recent higher education system more emphasizes successful college completion and class is used to check the current status of attending students on campus in terms of their credits, learning process, or others. Sometimes the class is intertwined with the concept of socioeconomic status (SES) to reflect the background of student social capital and studies often used to have the term to evaluate the effect of the student background for their targeted outcomes.

Reproduction of workers through higher education in traditional Marxism explains the possible training to meet ruling class elites. With the manipulated educational service based on the intention, the system performs to reproduce the class inequality and make labor a commodity for the interests of capitalist employers. The entire process of the learning environment on campus does the reproduction of the intended future workers all over again in the prior era. On the other hand, the revised view of Marxism educators has changed over time, and they feel contradiction in different parts of the logical justification to explain the purpose of educational service. The learning system is evaluated depending on how students perceive and create new value under a specific learning environment. This is a kind of transition from the passive training of potential workers to a comprehensive understanding of an individual as an independent human being.

\section{People and Behavior on Campus}

Current students interact with different campus members, including faculty, administrators, and the relationship creates the new value of human behavior and educational purpose. Marxism under modern interpretation may provide a clue to accelerate students' behavior under a more decentralized postsecondary education structure. The higher education institution is still struggling with its survival in the competitive market condition, and the Marxism-driven approach implies a possibility to recruit a specific student as advertising the unique learning process of the institution. The employable skills and academic program in the higher institution for better job placement from the practical emphasis of the job-centered theoretical lens train more specified future workers to the society and make new working cohorts. Compared to teenage students before the postsecondary education, college students are less likely to be easily affected by the peer groups' behavior and teacher's guide and build their plan for future career path through several academic entrances that institution provides. In the aspect, the traditional Marxism lens' that emphasizes the importance of peer group effects by the ruling class is weakened in there, and there are more possibilities to have possible cognitive growth through extracurricular activity, broaden the range of campus interaction.

The change of the theoretical lens is confirmed by two aspects of college students: student attitude and student behavior. These evaluate the perception of student and practical college experience on campus from the revised theoretical approach. First, students' attitude is not only depending on the ruling, dominant student group in the classroom and but also interact with each other according to their interests and different preference. It does not need to consider more about the potential outcomes, expected return, and possible ripple effect after the learning process. The revised theoretical lens acknowledges that college provides a more 
independent decision-making process to help individual career path, and the college students have more autonomy to design their academic planning under the campus climate. Second, students' behavior is not only remained as a passive role to follow the instructor's guide or institutional boundary and reflect their active engagement to diverse academic activity. While the initial lens from Marxism educators emphasizes more on the mechanism of educational purpose for better social requirements including employment, external needs, and other functional goals, the revised theory acknowledges the autonomy of students' behavior on campus and tries to explain why they do a particular activity in terms of their cognitive growth, perceived behavior, and other recognition.

\section{The connection between Higher Education and Marxism}

Marxism has made a significant change in the dominant paradigm in multiple fields, and the effect of the theoretical approach still gives the researchers essential messages. Current higher education also has a connection with the theoretical lens for the better institutional structure and functioning in the long run. The theoretical lens considers individual students as a producer under the process of social context, and the higher education system plays a role in training them for transforming progressive pedagogic practice (Neary, 2010). Through the transformation, the institution interacts with the society that requests different needs and moderate potential conflicts with external challenges. Neary and Winn's recent study (2016) discusses the frameworks for cooperative higher education. Beyond the traditional contradictory relationship of labor and property based on political economy, the proposed universal model covers private and public together in terms of applicable social integration. This situates the social intellect under an organizational setting from social history and drives to consider increasing the whole level of productivity in society.

Marxism affects the two types of higher education stakeholders: campus members and institutional behavior. Current marketized more elevated education privileges private, economic value, and emphasized the interpersonal relations with instructors for better learning outcomes (Nixon, Scullion, \& Hearn, 2018). There are increasing transactional and contractual pedagogic relationships between campus members. The emotional labors through interaction on campus share a certain academic tension, and the students under the learning environment increase the tendency to search for the invisible educational value beyond any countable measures (Öhman 2012). The Marxist educational theory has gone through the ups and downs of the change of the external environment. Rikowski (2002) points out that the evasion of Marxist educator's research to the new and exciting directions causes the shrinking of the theoretical lens. Discussed revision of the Marxism educational approach emphasizes the role of the individual as an independent person and respects the personality of campus members for more diversity. These new attempts of the revised Marxism provide some story on how campus members act differently according to their own needs.

\section{CONCLUSION}

After the collapse of communism in the regions of the world, the dominant power of Marxism has weakened over time, and the education field also has followed current trends. The emphasis of class for educational purposes does not work well to explain the individual behavior on the educational institution, and many circumstances of the higher education system do not readily support the theoretical lens. To overcome the crisis of the theoretical foundation for the explanation about reality, the revised Marxism educational approach tries to be combined with other theoretical lenses such as motivation theory. This means that they change their direction toward a more perceived attitude, recognition, and different cognitive decision-making process. The previous goal-oriented educational purpose - training of capable future workers - is not solely targeting college students, and they start to acknowledge the diverse needs and perceptions for their educational purpose. This is a trial for theoretical survival as well as a chance for the explanation of reality. College students are involved in many different types of learning processes in which they had no experience at this time for a better suitable member of society. The revised Marxism approach to overcome the previous limitation implies a lot of significance in which students could gain a lot of knowledge and insight based on new social values for diversity.

There are two suggestions to establish a better higher education system from the revised Marxism. The first is to review the traditional educational service that the old-fashioned Marxism has considered overtime, and change the social roles in the higher education system. Institutional leaders are frequently facing different internal or external needs for institutional mission and educational purposes. Revised notion and concept from 
Marxism implies some adoptive strategies to the decision-maker to survive the institution in the competitive higher education system. Institutional leaders could consider how their organization revises their educational service to meet external needs. There is no single solution to fulfill different requests outside, and the current institution is essential to consider the multi-dimensional aspects of its educational role. The new educational service is far from the traditional part of potential training workers and provides a unique social value for active participants of society. This reflects an aggressive academic role for attending students and requires systematic collaboration with externality. Second, the Marxism-driven approach gives the higher education researcher has an opportunity to reconsider the flexible social positions of postsecondary education. While the traditional higher education system has been required to train potential workers for industrial development or external needs, the current flexible environment needs multi-dimensional aspects of potential workers in society. The learning outcome may be shown up as diverse figures, such as a well-trained labor force, knowledge transfer, and technological development. Higher education based on the revised theoretical framework acknowledges the balance between unique educational roles and the apparent need for better learning outcomes.

This study also has some limitations. The analysis only focus on the theoretical approaches to explain the role of Marxism and tend to omit the practical interpretaion based on empirical evidence for the Marxism. Additionally, the flexible environment around current higher education system sometimes does not fit well for tradional interpretation of Marxism and required to have cutting-edged approaches of the Marxism in flexible higher education system over time. Further studies could examine the balanced view for a wide range of institutional roles or new structure of the higher education system in the long run.

\section{REFERENCES}

Allman, P., McLaren, P., \& Rikowski, G. (2005). After the Box People: The labor-capital relation as class constitution-and its consequences for Marxist educational theory and human resistance. Capitalists and Conquerors: A Critical Pedagogy Against Empire. Lanham MD: Rowman \& Littlefield, 135-165.

Alon, S. (2009). The evolution of class inequality in higher education: Competition, exclusion, and adaptation. American Sociological Review, 74(5), 731-755.

Anyon, J. (1994). The retreat of Marxism and socialist feminism: Postmodern and poststructural theories in education. Curriculum Inquiry, 24(2), 115-133.

Au, W. (2006). Against economic determinism: Revisiting the roots of neo-Marxism in critical educational theory. Journal for Critical Education Policy Studies, 4(2), 11-35.

Balibar, É. (1978). Irrationalism and Marxism. New Left Review, 107, 3-18.

Béchard, J. P., \& Grégoire, D. (2005). Entrepreneurship education research revisited: The case of higher education. Academy of Management Learning \& Education, 4(1), 22-43.

Brosio, R. (2004). Marxism, Still the Best Hunter of the Predator, Capitalism.

Brown, P. (1995). Cultural capital and social exclusion: some observations on recent trends in education, employment, and the labour market. Work, Employment and Society, 9(1), 29-51.

Blackledge, P. (2005). Freedom, Desire and Revolution: Alasdair Macintyre's Early Marxist Ethics. History of Political Thought, 26(4), p.696-720.

Cantwell, B., \& Maldonado-Maldonado, A. (2009). Four stories: Confronting contemporary ideas about globalization and internationalization in higher education. Globalisation, Societies and Education, 7(3), 289306.

Cole, M. (2005). Transmodernism, Marxism and social change: Some implications for teacher education. Policy Futures in Education, 3(1), 90-105.

Cole, M., Hill, D., \& Rikowski, G. (1997). Between postmodernism and nowhere: The predicament of the postmodernist. British journal of educational studies, 45(2), 187-200. 
Dordoy, A., \& Mellor, M. (2000). Ecosocialism and feminism: deep materialism and the contradictions of capitalism. Capitalism Nature Socialism, 11(3), 41-61.

Fourie, M. (2003). Beyond the ivory tower: Service learning for sustainable community development: Perspectives on higher education. South African Journal of Higher Education, 17(1), 31-38.

Greaves, N., Hill, D., \& Maisuria, A. (2007). Embourgeoisment, immiseration, commodification-Marxism revisited: A critique of education in capitalist systems. Journal for Critical Education Policy Studies, 5(1), 3872.

Heyneman, S. P. (2010). A comment on the changes in higher education in the former Soviet Union. European Education, 42(1), 76-87.

Hill, D. (2003). Global neo-liberalism, the deformation of education and resistance. Journal for Critical Education Policy Studies, 1(1), 1-30.

Hill, D. (2004). Books, banks and bullets: Controlling our minds - The global project of imperialistic and militaristic neo-liberalism and its effect on education policy. Policy Futures in Education, 2(3-4), 504-522.

Hill, D. (2005). State theory and the neoliberal reconstruction of schooling and teacher education. Critical theories, radical pedagogies, and global conflicts, 23-51.

Hill, H. C., Rowan, B., \& Ball, D. L. (2005). Effects of teachers' mathematical knowledge for teaching on student achievement. American educational research journal, 42(2), 371-406.

Hill, D. (2007). Critical teacher education, new labour, and the global project of neoliberal capital. Policy Futures in Education, 5(2), 204-225.

Hill, D., \& Kumar, R. (2012). Neoliberalism and its impacts. In Global neoliberalism and education and its consequences (pp. 32-49). Routledge.

Huckle, J. (2004). Critical realism: A philosophical framework for higher education for sustainability. In Higher education and the challenge of sustainability (pp. 33-47). Springer, Dordrecht.

Ibrahim, A. (2007). Linking Marxism, globalization, and citizenship education: Toward a comparative and critical pedagogy post 9/11. Educational Theory, 57(1), 89-103.

John Morgan, W. (2005). Marxism and moral education. Journal of Moral Education, 34(4), 391-398.

Johnston, R. J. (1989) Environmental Problems: Economy, Society and State. London: Belhaven.

Kellner, D. (2006). Marxian perspectives on educational philosophy: From classical Marxism to critical pedagogy. University of Los Angeles, California.

Lissovoy, N. D., \& McLaren, P. (2003). Educational 'accountability' and the violence of capital: A Marxian reading. Journal of Education Policy, 18(2), 131-143.

Malott, C. (2006). Schooling in an era of corporate dominance: Marxism against burning tires. Journal for Critical Education Policy Studies, 4(1).

Michael A. Peters (2019). Affective capitalism, higher education and the constitution of the social body Althusser, Deleuze, and Negri on Spinoza and Marxism, Educational Philosophy and Theory, 51(5), 465-473

Neary, M. (2010). Student as producer: a pedagogy for the avant-garde?. Learning Exchange, 1(1).

Neary, M., \& Winn, J. (2016). Beyond public and private: a framework for co-operative higher education.

Nixon, E., Scullion, R., \& Hearn, R. (2018). Her majesty the student: marketised higher education and the narcissistic (dis) satisfactions of the student-consumer. Studies in Higher Education, 43(6), 927-943.

Olssen, M. (2004). Foucault and Marxism: rewriting the theory of historical materialism. Policy Futures in Education, 2(3-4), 454-482. 
Öhman, M. (2012). Gender, class and transhumanism in Charles Stross' novel singularity sky: An intersectional analysis of post-singularity societies. Dissertation. Retrieved from http://urn.kb.se/resolve?urn=urn:nbn:se:ltu:diva-52904.

Papagiannis, G. J., Klees, S. J., \& Bickel, R. N. (1982). Toward a political economy of educational innovation. Review of Educational Research, 52(2), 245-290.

Perry, L. B., \& Tor, G. H. (2008). Understanding educational transfer: Theoretical perspectives and conceptual frameworks. Prospects, 38(4), 509-526.

Qi, J. (1997). Postmodernism and Marxism: What is called into question in the educational discourse? Annual Meeting of Educational Research Association, March 24-28.

Rikowski, G. (2002). Prelude: Marxist educational theory after postmodernism. Marxism Against Postmodernism in Educational Theory, 15-32.

Soper, K. (1999). The politics of nature: Reflections on hedonism, progress and ecology. Capitalism Nature Socialism, 10(2), 47-70.

Steele, T., \& Taylor, R. (2004). Marxism and adult education in Britain. Policy Futures in Education, 2(3-4), 578592.

Torres, C. A. (1995). Chapter 6: State and education revisited: Why educational researchers should think politically about education. Review of Research in Education, 21(1), 255-331.

Trowler, P. (2001). Captured by the discourse? The socially constitutive power of new higher education discourse in the UK. Organization, 8(2), 183-201.

Whitehead, J. (2009). How do I influence the generation of living educational theories for personal and social accountability in improving practice? Using a living theory methodology in improving educational practice. In Research Methods for the self-study of practice (pp. 173-194). Springer, Dordrecht.

Young, M. (2012). Education, globalisation and the 'voice of knowledge. In Educating for the Knowledge Economy? (pp. 151-163). Routledge. 